\title{
Application of Spatial and Network Analysis to Evaluate Shelter Plan for Tsunami Evacuation
}

\author{
Sutikno, S. ${ }^{* *}$ and Murakami, K. $^{2}$
}

\begin{abstract}
This study proposes a method for evaluating shelter plan for emergency evacuation prior to a tsunami based on service area analysis. The evacuation service areas are generated using both spatial and network analysis based on Geographic Information System (GIS). A case study in Pacitan city, East Java Province, Indonesia which is located in the South coastal area of Java Island, is picked as study area. The field has a possibility of suffering tsunami disaster because of the movement of Indo-Australian plate and Eurasian plate. The simulation result shows that the current evacuation shelters arranged by local government are not easy to access if tsunami occurs. About 50\% of the residents do not have enough time to evacuate to the shelters because many shelters are located far from residential area. Utilizing public buildings around residential area for temporary shelters proposed in this study, about $96 \%$ residents in inundation area have sufficient time to evacuate to the shelters.
\end{abstract}

Keywords: GIS; spatial and network analysis; tsunami evacuation.

\section{Introduction}

Tsunamis are a series of enormous waves that are generated by an underwater disturbance such as an earthquake, landslide, volcanic eruption, or meteorite. All tsunamis are potentially dangerous, even though they may not damage every coastline they strike. Tsunami attacks are categorized as one of the natural disasters which cannot be precisely predicted on where and when it will occur. Up to date, it has caused quite many destructive impacts on our society, such as human casualties, injuries, and property damages.

After the catastrophic damages of the 1994 Java tsunami, some local governments in East Java Province, Indonesia realized that their areas have a very high risk for tsunami disasters. Since this event, they have made significant efforts to reduce vulnerability of their regions to tsunami disasters. For example, Pacitan, East Java Province, Indonesia has provided a tsunami hazard map that included evacuation shelter and evacuation routes. It is very important that those evacuation shelters and evacuation routes are allocated based on a reasonable method to ensure safe evacuation.

\footnotetext{
${ }^{1}$ Department of Civil Engineering, Faculty of Engineering, University of Riau, Pekanbaru, INDONESIA.

${ }^{2}$ Department of Civil and Environmental Engineering, University of Miyazaki, 1-1 Gakuen Kibanadai Nishi Miyazaki, JAPAN.

* Corresponding author; e-mail: ssutiknoyk@yahoo.com
}

Note: Discussion is expected before November 1" 2015 , and will be published in the "Civil Engineering Dimension" volume 18, number 1, March 2016.

Received 20 April 2015; revised 13 August 2015; accepted 21 August 2015.
This study utilized a method for evaluating public shelter plan for safe evacuation prior to a tsunami based on the consideration of accessibility and capacity of the evacuation shelter. In the evaluation of public shelter plan, this study considers the service area of evacuation shelter. The service area is defined as the minimum area from which the residents can reach the nearest evacuation shelter from their house by foot within a clearance time. The clearance time is defined as the minimum time until the approach of the first tsunami wave after the official warning of tsunami evacuation. The evacuation service areas are generated using both spatial and network analysis based on Geographic Information System (GIS).

\section{Study Area}

Pacitan, the capital of Pacitan Regency, is situated between $07^{\circ} 11^{\prime} 00^{\prime \prime}$ and $07^{\circ} 14^{\prime} 00^{\prime \prime}$ South latitude and $111^{\circ} 04^{\prime} 30^{\prime \prime}$ and $111^{\circ} 09^{\prime} 30^{\prime \prime}$ East longitude. Pacitan is one of the harbor cities in East Java Province, Indonesia. It is located in the Southern coastal area of Java Island, as shown in Figure 1. The total population of Pacitan is around 47,000 people [1]. Since the lowland area has been developed as the Governance Center, the population is concentrated very highly within this region, as shown in Figure 1. Along the coastal area, Teleng Ria beach has been recognized as a popular tourism area, and this area is also utilized as a fishing port. Many people are in this coastal area for their particular activities, and the residential areas spread landward from the coastline. 

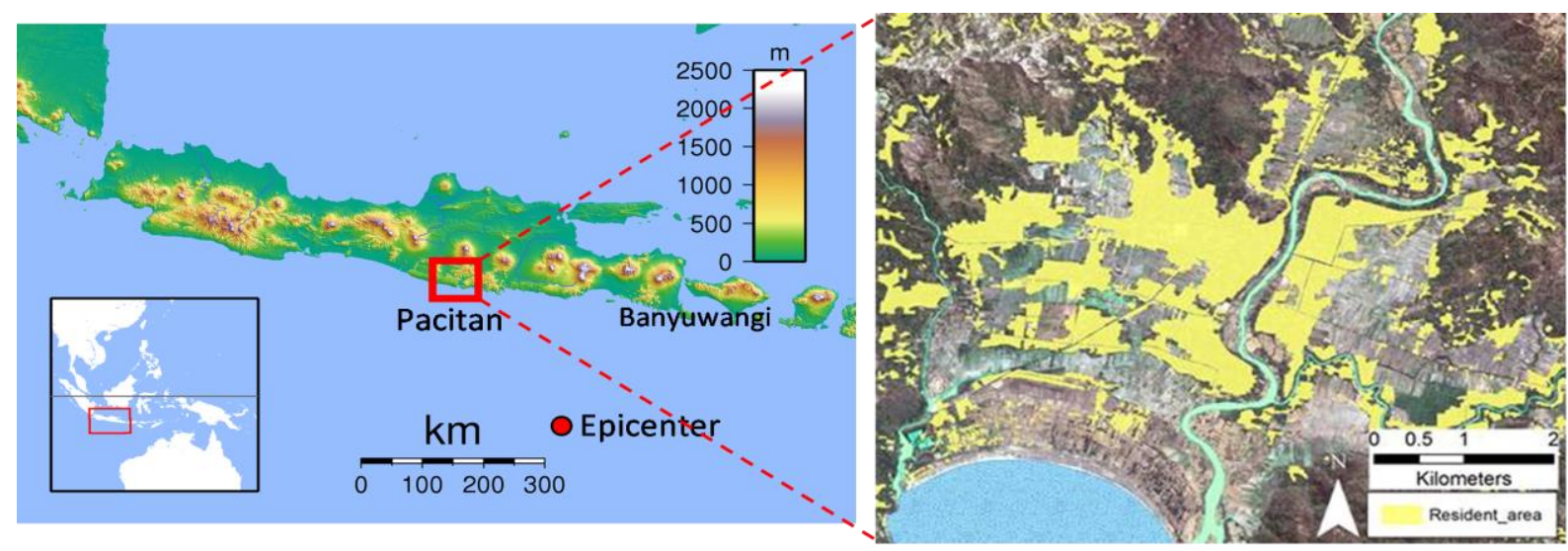

Figure 1. The Location of Pacitan and the Residential Area in the City of Pacitan, East Java

Historically, there have been no significant tsunami events in Pacitan. However, the city potentially could have a devastating tsunami in the future because it is located on the southern coastal area of Java Island that is exposed to the subduction zone between the Eurasian Plate and the Australia Plate. On June 3, 1994, a large earthquake of surface wave magnitude (Ms) 7.2 occurred off the Southeast coast of Java Island, Indonesia. The earthquake produced a devastating tsunami on East Java and on Bali Island. About 50 minutes after the main shock, a sizable tsunami hit the coast, inflicting heavy damage on several coastal villages in East Java Province. A total of 223 persons were killed and 15 persons were missing, mainly in the Banyuwangi Regency, Java Island [2]. Pacitan, which is also located in the South coastal area of Java Island, is very vulnerable to earthquakes as well as tsunamis when hypocentral regions locate close to the coastal area.

\section{Tsunami Hazard Map of Pacitan City}

When this research was conducted, there was no official tsunami hazard map had been developed for Pacitan City based on numerical simulation. Mardiatno [3] conducted tsunami inundation modeling for the coastal area of Pacitan using TUNAMI model. The TUNAMI model is a numerical model for tsunami propagation that was developed by Imamura et.al. [4]. In his simulation, the hypothetic epicenters were located at $111.0^{\circ} \mathrm{E},-9.5^{\circ} \mathrm{S}$, and the earthquake magnitudes were set as $7.5,8.0$, and 8.5 Ms. The 8.5 Ms earthquake was selected as the worst scenario for tsunami hazard potential. The map of the tsunami hazard potential using this scenario is shown in Figure 2. The results of this simulation were used in this study. Most of the residential areas shown in Figure 1 were inundated by the tsunami that followed the earthquake. Inundations of more than 2 meters spread signifi- cantly in the landward direction because of the topography of Pacitan. The existence of a large river close to the City allowed a greater intrusion of the tsunami into the land area.

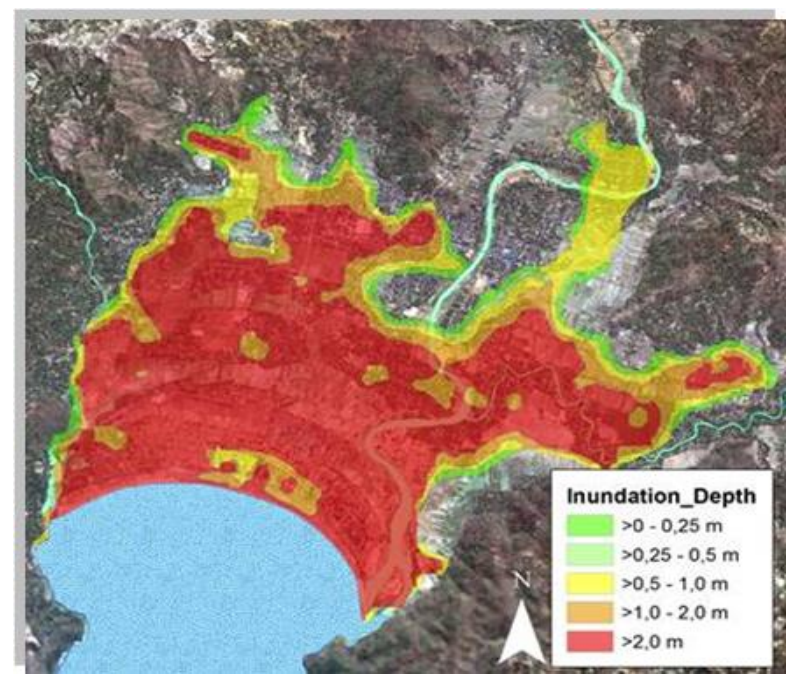

Figure 2. Tsunami Inundation Area in Pacitan

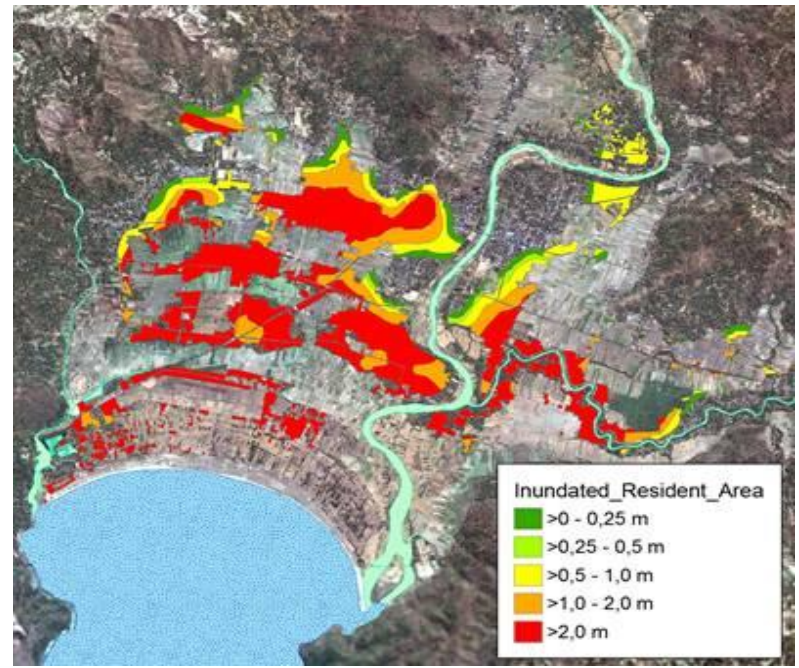

Figure 3. Map of Inundated Residential Areas in Pacitan 
Figure 3 shows the inundated residential areas in Pacitan City. Residential areas in this study include areas where there are houses, government offices, schools, shop-houses, market buildings, and others public facilities. It is assumed that around $5.4 \mathrm{~km}^{2}$ of the total of $10.8 \mathrm{~km}^{2}$ of residential areas in Pacitan City were inundated, and around $76 \%$ of them were inundated by tsunami wave that was more than $1 \mathrm{~m}$ high. These results occurred because the residential areas are located mainly on the low-land area.

\section{Shelter Plan for Tsunami Evacuation in Pacitan City}

In 2010, the local government of Pacitan designated evacuation routes on the map and designated 13 evacuation shelters in case of a tsunami disaster, as shown in Figure 4. As shown in the map, most of the evacuation shelters designated by the local government are the open-space areas located in the hilly terrain. Based on field survey from January 20 to January 21, 2014, this study found that there was no special sign in Pacitan to designate evacuation routes or shelters. Alternatively, this study proposes some evacuation shelters that are identified based on the local wisdom in Pacitan. Most of Pacitan's people are muslim, and they have a unique culture. They usually have at least one mosque for each village that is used by the residents for praying five times every day. The mosques usually have traditional sound instruments, such as a drum (bedug in Indonesian), for inviting people to pray together. Those instruments are also used to deliver various announcements for the community. Recently, they have been used as a part of the tsunami earlywarning systems in Indonesia. The mosque is recognized as a quasi-public place for residential people, and it usually has a sturdy structure with several floors. Some types of mosques withstood the 2004 Aceh earthquake and tsunami event because of their unique architecture, while other buildings near the mosque collapsed. Historically many other traditional buildings in other area in Indonesia have survived similar earthquake [5]. Based on those facts and the culture of Pacitan, it is proposed that the mosques should be used to provide temporary shelter when a tsunami is imminent.

Based on field survey, this study identified 33 public buildings that could be used for evacuation shelter. Those buildings were estimated to have sufficient height to elevate evacuee above the level of tsunami inundation, and have strength and resiliency needed to resist the effect of tsunami waves. Those proposed evacuation shelters consists of 20 mosques and 12 other public buildings, such as hospitals, schools, hotels, and government offices (Figure 5).

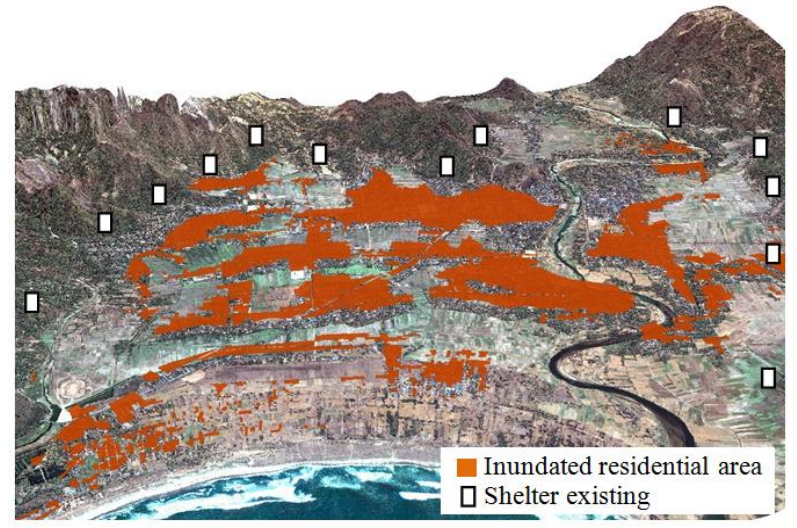

Figure 4. Existing Shelter Plan Allocated by Local Government

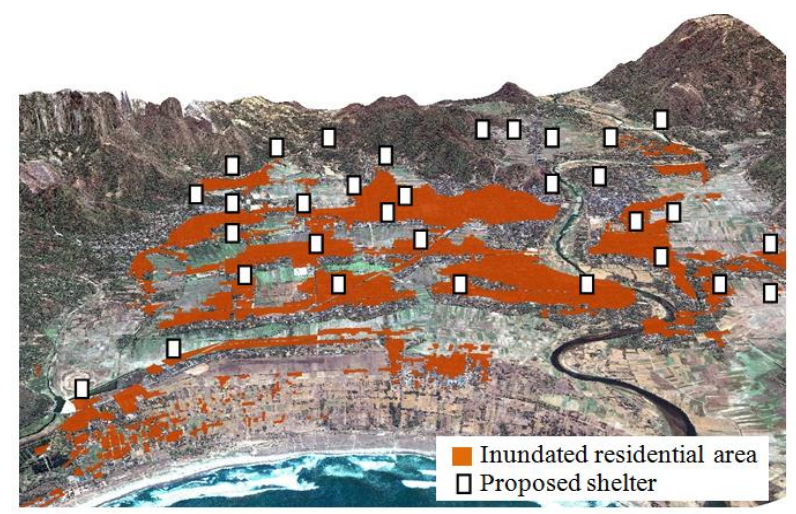

Figure 5. Proposed Shelter Plan from this Study

There are 15 public buildings which are located in the inundation area; these buildings possibly could serve as temporary shelters because all of these buildings have more than two floors, and could provide temporary shelters on the second floor.

\section{Spatial and Network Analysis based on GIS}

\section{Evacuation Service Area}

A network service area is a region that encompasses all accessible streets that are within specified limits of impedance. For instance, 5-minute service area for a point includes all the streets that can be reached within five minutes from that point. Evacuation service area is the minimum area from which the residents can reach the nearest evacuation place from their house by foot within a clearance time. The evacuation service areas can be generated using both spatial and network analysis based on Geographic Information System (GIS). Service areas created by Network Analyst also help evaluate accessibility [6]. Once built, users can use service areas to identify how many people, how much land, or the quantity of anything else that is within the neighborhood. Using Arc GIS Network Analyst tool, the service areas around any location on a network can be found [7]. 
In this study, service area simulations are performed to investigate how many people can evacuate to the nearest shelter facilities before the tsunami arrives. The simulation of service area is used to evaluate evacuation shelter plan focusing on accessibility and capacity of evacuation shelters. The simulations consist of seven steps, i.e., preparing data, developing the network dataset, creating the analysis layer, adding network locations, setting analysis properties, performing the analysis, and displaying the results. There are some data that must be prepared for performing the network analysis, such as: road networks coordinate of evacuation shelters, and Tsunami inundation map. This study utilizes road networks as facilities for evacuees to move to the safety of the evacuation places. In the ArcGIS Network Analyst, evacuation shelters are denoted as facilities. They are the safe places where evacuees must go when a tsunami is imminent. In the study areas, the local governments have already allocated some buildings or places as evacuation shelters. The tsunami inundation map presents inundation areas, which is the main focus in this analysis because the inundation areas should be covered by the service area generated from this analysis in order to arrange safe evacuation.

Figure 6 shows an example of service area results based on the simple performance of network analysis. It shows the three service areas that are within walking times of 5,10 , and 15 minutes from the shelter. This means that people in those areas can reach the three facilities within 5, 10, and 15 minutes, respectively. In the case of an evacuation due to an impending tsunami, the target area for evacuation is the tsunami inundation area. The service area of evacuation places should cover the inundation area. In that case, the covered service area on inundation area means that people who live in the covered area will have sufficient time to walk to the evacuation places.

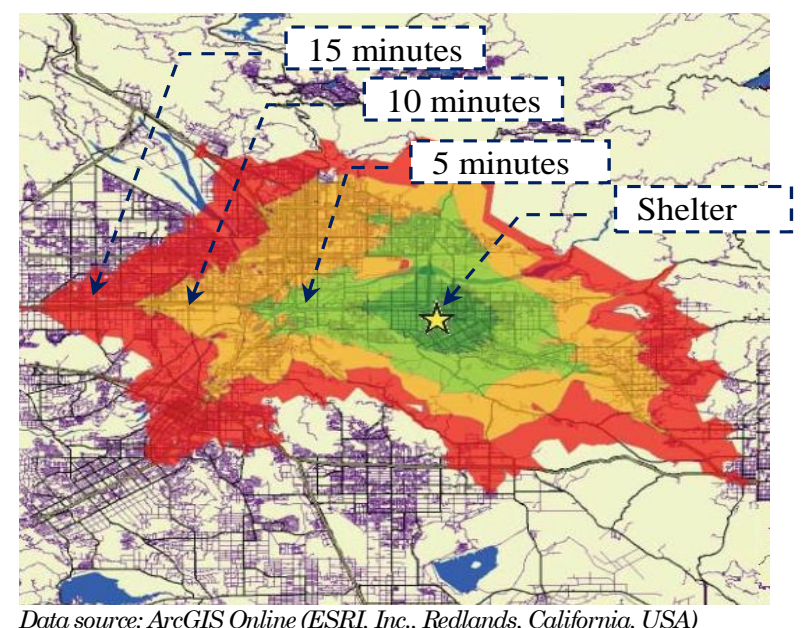

Figure 6. Example of Service Area as a Result of Performing Network Analysis

\section{Setting for Network Analysis}

Tsuji et al. [2] reported that after the 1994 Java earthquake, a tsunami attacked Pacitan approximately within 50 minutes after the earthquake. Judging from the current tsunami warning transmission system, about 20 minutes will be consumed after the earthquake just to alert the population. Based on above assumptions, the clearance time to reach an evacuation shelter is considered only 30 minutes. In the case of tsunami evacuation, the local authorities strongly recommend that the evacuees walk to the designated shelters. The walking speed during an evacuation differs significantly, depending on age, physical strength, state of health, and degree of handicap. However, since it is difficult to take these differences into consideration in this study, it is assumed that all people walk on a plain surface with an average speed of $3.6 \mathrm{~km} / \mathrm{h}$ [8]. Thus, the maximum distance the evacuees could cover in 30 minutes is estimated to be $1.8 \mathrm{~km}$. Thus, the service areas are generated based a maximum distance of $1.8 \mathrm{~km}$ along the evacuation route.

\section{Evaluation of Existing Shelter Plan}

In the evaluation of existing shelters, this study considers both accessibility and accommodation capacity of the evacuation building. Accessibility in this study refers to the shortest path that evacuees can take to reach the evacuation places, which can be determined by analyzing the service area. In the evaluation of the service areas, this study focuses on the residential areas that are located in the tsunami inundation area, as illustrated in Figure 3. The results of the simulated service area both for existing and proposed shelter plan base on network analysis on GIS are shown in Figure 7. The figure shows the service areas over the inundated residential areas, and the inundated residential areas that are not covered by service areas.

Fig. 7(a) shows that the service area of the existing shelter plan covers only about $49 \%$ of inundated residential area. It means that about $51 \%$ residents who are assumed reside in residential area will be stricken by tsunami wave before they arrive in the evacuation shelter. This occurred because the location of evacuation shelters arranged by the local government is too far from the inundated residential area, many residents would not have enough time to reach the evacuation shelters before the tsunami arrived. In this case, more than half of residents do not have sufficient time to get to the evacuation shelters. This means that the current arrangement of evacuation shelter is not enough for tsunami mitigation plan in Pacitan city. 


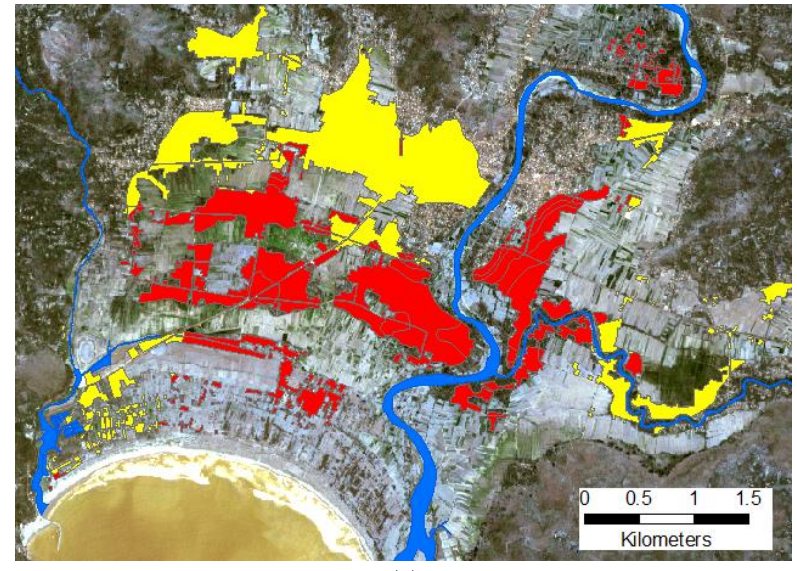

(a)

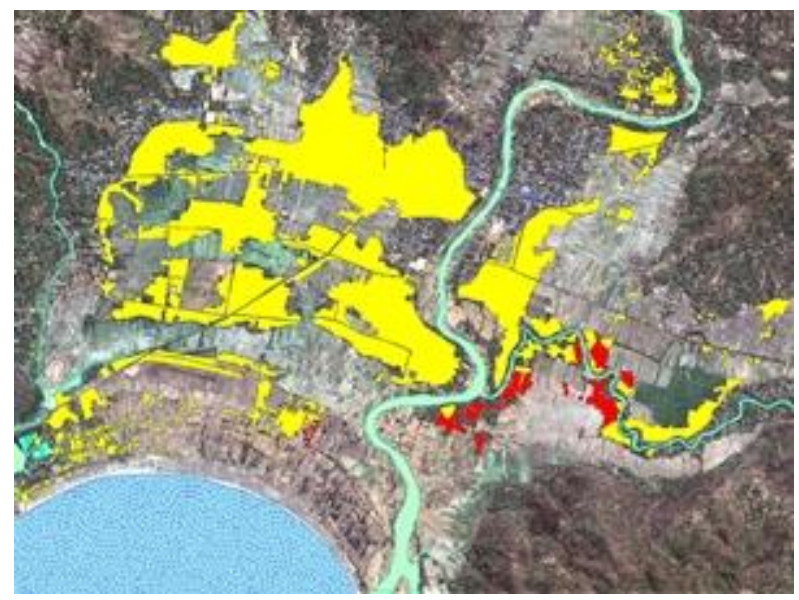

(b)

Service area covered on inundated resident area

Inundated resident area cannot be covered by service area

Figure 7. Map of Inundated Residential Areas that are Covered by a Service Area in Existing (a) and Proposed Shelter Plan (b)

\section{Proposed Shelter Plan Alternative}

Based on evaluation of existing evacuation shelters, this study proposed a new shelter allocation by utilizing public buildings. This study proposed 33 public buildings that can be used for evacuation shelters. Most of the public buildings are mosques which are known as part of tsunami warning system in Pacitan city. The generating service area for proposed shelter allocation increases significantly and almost covers all of the residential areas as shown in Fig. 7b. In this case, the service area covers $96 \%$ of the inundated residential area. It means that about $96 \%$ people who reside in inundated resident area will have sufficient time to reach evacuation shelters before tsunami arrives.

However, in order to evaluate the proposed shelter allocation, it is also important to consider the capacity of evacuation shelter in comparison with the number of evacuee that has to be accommodated in each shelter. Figure 8 shows service area of each shelter on shelter plan proposed in this study. The number of evacuees that have to be accommodated by each shelter can be estimated by multyplying the population density and the area of each service area of the shelter. Comparison of the number of evacuee that has to be accommodated and the capacity of the shelter is shown in Figure 9.

The capacity of an evacuation shelter refers to the maximum acceptable number of evacuees that can be appropriately accommodated, which is determined by the number of people and the total area of the available living space. This study used a ratio of $1.65 \mathrm{~m}^{2} /$ person. This ratio can be used to calculate the maximum acceptable number of evacuees [9]. The total capacity of all the shelters is estimated to be approximately 12,964 people as shown in Table 1.

Figure 9 shows that there are eight shelters with capacities less than the numbers of evacuees they must accommodate, i.e., S1, S3, S4, S5, S19, S23, S25, and S31. Shelter S3 and S5 are located in very densely population but their capacity are relatively small. These shelters, namely Masjid An Hikmah Bangunsari (S3) and Masjid Ainun Yakin are the mosques which should be enlarge in order to be a part of tsunami mitigation strategy for evacuation shelters beside their main purpose as praying places.

Table 1 shows that, by considering only the accessibility of the evacuation shelters regardless of whether there is enough capacity, 12,473 residents have sufficient time to reach an evacuation shelter, which is about $96 \%$ of the residents in the inundation area. However, by considering the accommodation capacity of the public shelters, only about 6,509 evacuees (about 51\%) can be accommodated by the available shelters, which mean that almost 5,963 people (49\%) cannot be accommodated.

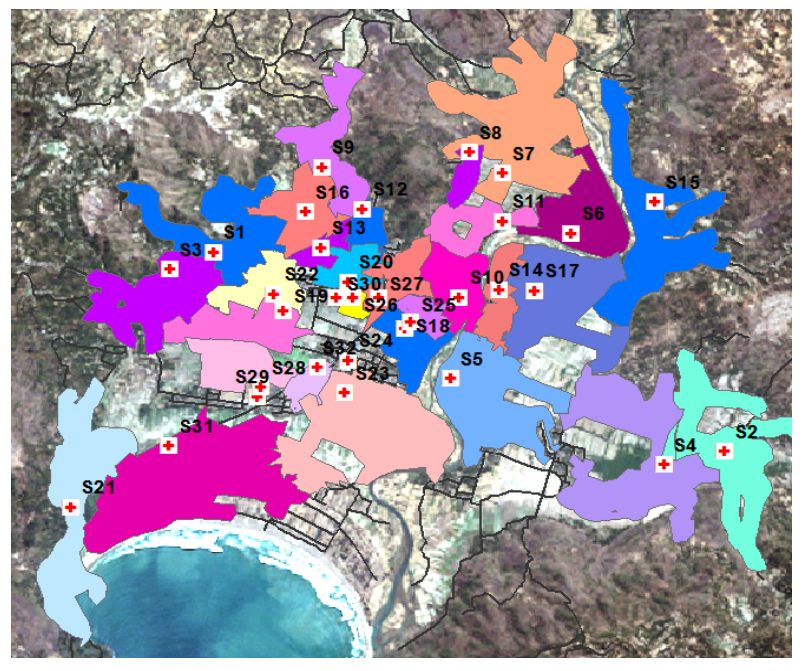

Figure 8. Service Area of Each Evacuation Shelter on Proposed Shelter Plan in Pacitan 


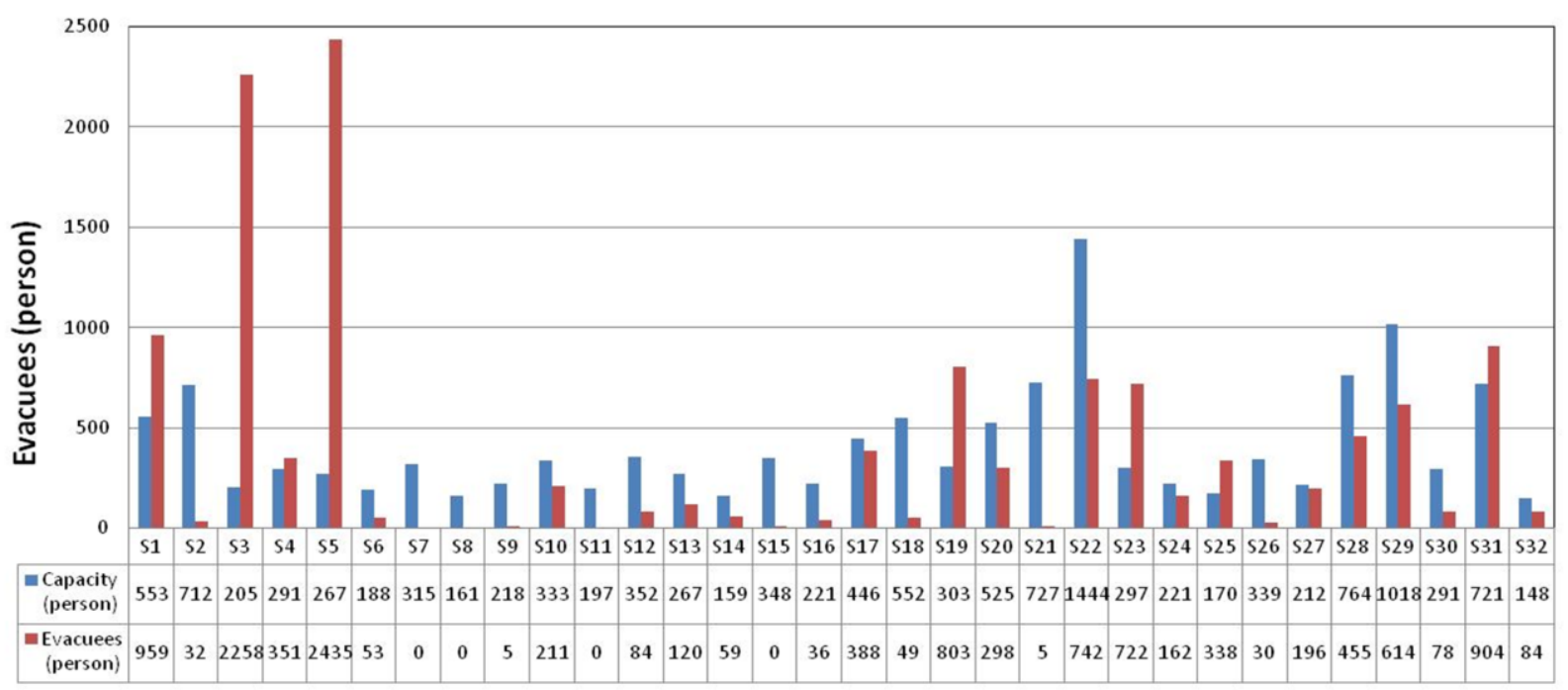

Figure 9. The Capacity of Public Shelter and the Number of Evacuee who Live in their Service Area

Table 1. The Comparison of Shelter Capacity and the Number of Resident who has Sufficient Time to Evacuate to the Shelter on Proposed Shelter Plan in this Study

\begin{tabular}{|c|c|c|c|c|c|c|c|c|c|}
\hline No & Prospective Shelters Name & $\begin{array}{l}\text { Shelters } \\
\text { Code }\end{array}$ & $\begin{array}{l}\text { Number } \\
\text { of Floor }\end{array}$ & $\begin{array}{l}\text { Capacity } \\
\text { (person) }\end{array}$ & $\begin{array}{l}\text { Service } \\
\text { Area } \\
\text { (person) }\end{array}$ & Condition & $\begin{array}{c}\text { Evacuee can } \\
\text { be accommo- } \\
\text { dated (person) }\end{array}$ & $\begin{array}{c}\text { Evacuee cannot } \\
\text { be accommodated } \\
\text { (person) }\end{array}$ & $\begin{array}{c}\text { Free space } \\
\text { (person) }\end{array}$ \\
\hline & \multicolumn{9}{|l|}{ Non-Inundated Mosques } \\
\hline 1 & Masjid Al Muhajirin Bangunsari & $\mathrm{S} 1$ & 1 & 553 & 595 & Insufficient & 553 & 406 & 0 \\
\hline 2 & Masjid Kayen & $\mathrm{S} 2$ & 1 & 712 & 32 & Sufficient & 32 & 0 & 681 \\
\hline 3 & Masjid An Hikmah bangunsari & S3 & 1 & 205 & 2258 & Insufficient & 205 & 2053 & 0 \\
\hline 4 & Masjid Syuhada Sukaharjo & $\mathrm{S} 4$ & 1 & 291 & 351 & Insufficient & 291 & 60 & 0 \\
\hline 5 & Masjid Ainul Yakin & S5 & 1 & 267 & 2435 & Sufficient & 267 & 2168 & 0 \\
\hline 6 & Masjid Ds Nanggungan 1 & S6 & 1 & 188 & 53 & Sufficient & 52 & 0 & 135 \\
\hline 7 & Masjid Ds Nanggungan 2 & $\mathrm{~S} 7$ & 1 & 315 & 0 & Sufficient & 0 & 0 & 315 \\
\hline 8 & Masjid Ds Nanggungan 3 & $\mathrm{~S} 8$ & 1 & 161 & 0 & Sufficient & 0 & 0 & 161 \\
\hline 9 & Masjid Kel Pucangsewu 1 & S9 & 1 & 218 & 5 & Sufficient & 5 & 0 & 213 \\
\hline 10 & Masjid Mujahidin Tanjungsari & $\mathrm{S} 10$ & 1 & 333 & 211 & Sufficient & 211 & 0 & 122 \\
\hline 11 & Masjid Ds Nanggungan 4 & $\mathrm{~S} 11$ & 1 & 197 & 0 & Sufficient & 0 & 0 & 197 \\
\hline 12 & Masjid Kel Pacitan & S12 & 1 & 352 & 84 & Sufficient & 84 & 0 & 267 \\
\hline 13 & Masjid Kel Pucangsewu 2 & $\mathrm{~S} 13$ & 1 & 267 & 120 & Sufficient & 120 & 0 & 147 \\
\hline 14 & Masjid Arjowinangun & $\mathrm{S} 14$ & 1 & 159 & 59 & Sufficient & 59 & 0 & 100 \\
\hline 15 & Masjid Ds Purworejo & $\mathrm{S} 15$ & 1 & 348 & 0 & Sufficient & 0 & 0 & 348 \\
\hline 16 & Masjid At Taqwa & S16 & 1 & 221 & 36 & Sufficient & 36 & 0 & 185 \\
\hline 17 & Masjid Ngaglik & S17 & 1 & 446 & 388 & Sufficient & 388 & 0 & 58 \\
\hline \multirow{2}{*}{\multicolumn{10}{|c|}{$\begin{array}{l}18 \text { Masjid Jami Darusalam Baleharjo } \\
\text { Inundated Mosques }\end{array}$}} \\
\hline & & & & & & & & & \\
\hline 1 & Masjid LDII & S19 & 2 & 303 & 803 & Insufficient & 303 & 500 & 0 \\
\hline \multirow[t]{2}{*}{2} & Masjid Agung & $\mathrm{S} 20$ & 2 & 525 & 298 & Sufficient & 298 & 0 & 227 \\
\hline & Public Buoldings & & & & & & & & \\
\hline 1 & Hotel Graha Prima & $\mathrm{S} 21$ & 2 & 727 & 5 & Sufficient & 5 & 0 & 722 \\
\hline 2 & PN Pacitan & $\mathrm{S} 22$ & 2 & 1444 & 742 & Sufficient & 742 & 0 & 702 \\
\hline 3 & STKIP PGRI & $\mathrm{S} 23$ & 2 & 297 & 722 & Insufficient & 297 & 425 & 0 \\
\hline 4 & SDN Ploso 1 & $\mathrm{~S} 24$ & 2 & 221 & 162 & Sufficient & 162 & 0 & 58 \\
\hline 5 & SMU Muhamadiyah & $\mathrm{S} 25$ & 2 & 170 & 338 & Insufficient & 170 & 169 & 0 \\
\hline 6 & SDN baleharjo 2 & $\mathrm{~S} 26$ & 2 & 339 & 30 & Sufficient & 30 & 0 & 310 \\
\hline 7 & SMP 2 Pacitan & $\mathrm{S} 27$ & 2 & 212 & 196 & Sufficient & 196 & 0 & 16 \\
\hline 8 & SMA 1 Pacitan & $\mathrm{S} 28$ & 2 & 764 & 455 & Sufficient & 455 & 0 & 309 \\
\hline 9 & SMK 1 Pacitan & $\mathrm{S} 28$ & 2 & 1018 & 614 & Sufficient & 614 & 0 & 404 \\
\hline 10 & RSUD Pacitan & S30 & 2 & 291 & 78 & Sufficient & 78 & 0 & 212 \\
\hline 11 & Smk Bina Karya & S31 & 2 & 721 & 904 & Insufficient & 721 & 183 & 0 \\
\hline \multirow[t]{2}{*}{12} & MAN & $\mathrm{S} 32$ & 2 & 148 & 84 & Sufficient & 84 & 0 & 65 \\
\hline & & & & 12,964 & 12,473 & & 6,509 & 5,963 & 6,455 \\
\hline
\end{tabular}


So, if $96 \%$ of the evacuees reach the shelters before the tsunami strikes, the shelters only have enough space to accommodate $51 \%$ of the arriving evacuees. This occurs because several shelters do not have adequate capacity to accommodate the evacuees in their service area. Conversely, there are 24 other shelters that have free space that could accommodate more evacuees. Totally there are 6.455 more free spaces for people that can be accommodated in those public shelters.

Above discussion concludes that the allocation of proposed evacuation shelter is easier accessed by local residents than the existing shelter allocated by local government because they are located around residential area. However, there are eight evacuation shelters which have not enough capacity compared with the number of evacuee that has to be accommodated. Those shelter need to be enlarged in order to be part of tsunami mitigation system in Pacitan.

\section{Conclusions}

This study applied spatial and network analysis for evaluating existing shelter plan for emergency evacuation prior to a tsunami based on the consideration of accessibility and capacity of evacuation shelter. The simulation result shows that the current evacuation shelters arranged by local government are not easy to access by local residents if tsunami occurs. About $51 \%$ of the residents who stay in inundation area do not have enough time to evacuate to the nearest shelters because most of shelters are located far from residential area. By utilizing public buildings around residential area for temporary shelters proposed in this study, about 96\% residents in inundation area have sufficient time to evacuate to the shelters. However, considering the accommodation capacity of the shelters, only about $51 \%$ residents can be accommodated by the available shelters, because several shelters do not have adequate capacity to accommodate the evacuees in their service area. This study recommends to increase the capacity of those evacuation shelters for tsunami mitigation strategy in Pacitan City.

\section{References}

1. Bappeda_Pacitan, Development Planning of The Settlement Area in Pacitan City, Pacitan, 2002.

2. Tsuji, Y., Imamura, F., Matsutomi, H., Synolakis, C., Nanang, P., Jumadi, Harada, S., Han, S., Arai, K., and Cook, B., Field Survey of The East Java Earthquake and Tsunami of June 3, 1994, Pure Appl. Geophys. 144(3-4), 1995, pp. 839-854.

3. Mardiatno, D., Tsunami Assessment using Scenario-based Approach, Geomorphological Analysis and Geographic Information System, A Case Study in South Coastal Areas of Java IslandIndonesia, University of Innsbruck, Austria, 2008.

4. Imamura, F., Yalciner, A. C., and Ozyurt, G., Tsunami Modelling Manual (TUNAMI model), Disaster Control Research Center, Tohoku University, Sendai, Japan, 2006. [Online]. Available: http://www.tsunami.civil.tohoku.ac.jp/hokusai3/J/ projects/manual-ver-3.1.pdf. [Accessed: 21-Aug2015].

5. Lumantarna, B., Learning from Local Wisdom: Friction Damper in Traditional Building, Civ. Eng. Dimens., 14(3), 2012, pp. 190-195.

6. Sutikno, S., Murakami, K., and Suharyanto, A., Evacuation Risk Analysis against Tsunami Hazard Based on Spatial and Network Analysis on GIS, Proceedings of the Twentieth (2010) International Offshore and Polar Engineering Conference, 2010, 7, pp. 599-604.

7. Mandloi, D., Sandhu, J., and Chandrasekhar, T., ArcGIS Network Analyst Tutorial. New York Street, Redlands: ESRI, 2008.

8. Potangaroa, R., Tsunami Disaster Risk Reduction-Practical Guidelines for the Indonesian Context, International Conference on Building Education and Research (BEAR) "Building Resilience,", 2008, pp. 606-617.

9. Xu, W., Okada, N., Hatayama, M., and Takeuchi, Y., A Model Analysis Approach for Reassessment of the Public Shelter Plan Focusing both on Accessibility and Accommodation Capacity for Residents - Case Study of Nagata Ward in Kobe City, Japan, J. Nat. Disaster Sci., 28(2), 2008, pp. 85-90. 